Let this movable matter be kept in a state of steady motion relative to the sphere, by actions and reactions between it and the sphere, without the action of any external force :

Let $\mathrm{P}$ be the pole of the axis of rotation of the sphere, which will also be its momental axis :

Let $Q$ be the momental axis of the total motions of the movable matter relative to the sphere:

Let $\mathrm{I}$ be the moment of inertia of the sphere, and $\mathrm{M}$ the total moment of momentum of all the movable matter around the axis $Q$ :

Then shall the sphere take such a motion that the pole $P$, while remaining in a fixed direction in space from the centre of the sphere, shall move steadily relatively to the matter of the sphere around the pole $Q$, with an angular velocity $\mathrm{M} / \mathrm{I}$.

The application of this theorem to the case of the earth surrounded by its oceanic and atmospheric envelopes can now readily be seen. To obtain the value of $M$, we may roughly estimate the ratio of the moment of inertia of the earth to that of the ocean as 2600 , and to that of the atmosphere as I, 000,000

Observations, as discussed by Chandler, and interpreted by theory, indicate an annual change in the pole of the earth, which would be produced by a primary oscillation back and forth through a length of ten feet, or a revolution in a circle having a diameter of five feet. The former motion would, according to the theorem, be the necessary result of a general motion of the oceans on the two sides of the earth, which, at the point where the motion was a maximum, would be 2600 times as great. Approximately this motion would be represented by a continuous flow of the central parts of the Pacific ocean toward the pole of about $\mathbf{I} 50$ feet per day, with a correspondingly larger motion of the Atlantic in the opposite direction; followed by an opposite oscillation during the other six months. If, as may seem very likely, there cannot be so great a differential flow as this through Behring Strait, and between the American and Asiatic continents, it will be necessary to suppose a more rapid flow elsewhere, or a sufficient vortex in the currents of the Atlantic and Pacific oceans. Whether the currents in these oceans are deep enough to produce the observed effect must be left to hydrographers to decide.

Passing to the atmosphere, the excess of motion through one season over that of the other season, to and from the north direction, amounting to 4000 miles in six months, or say twenty miles per day, would also account for the observed change. In these statements respecting the required motions of the earth and atmosphere, I have presupposed a motion around an invariable momental axis. If the motions are such that their momental axis moves around the earth in the course of a year, the required differential motions between the opposite seasons would be only half as great.

In what precedes I have spoken of the earth as a sphere, and considered only differential motions. The actual earth being a spheroid, the motion of the pole already described would not be continuous. The actual effect of oceanic and atmospheric currents of a permanent character on the terrestrial spheroid would be to displace the mean pole of the earth from its pole of figure to such a point of equilibrium that the motion described in the theorem would be neutralised by an equal and opposite Eulerian motion, due to the ellipticity of the spheroid. The actual effect would be a revolution of the terrestrial pole, according to the known laws of rotation, around the central point of equilibrium thus fixed in 427 days. Just what the displacement is can be only a matter of guess-work; from the known magnitude of the ocean currents they might produce a displacement ranging from ten to twenty feet.

A brief statement of the character of the theoretical variations of the latitude, due to these causes, may not be inappropriate. Since the directions of the currents of the air and ocean go through an annual period, we should expect a corresponding period in the latitude. Since, however, the amount of the annual change varies irregularly from year to year, though remaining constant in the general mean, the amplitude of the annual term should be subject to small variations from time to time, while preserving its mean value unchanged from age to age.

On the other hand, the amplitude of the Eulerian motion being permanently increased or diminished by every meteorological change, may be expected to vary its amplitude in a slow and irregular manner from decade to decade. The Eulerian motion, having a period of 427 days, ought to be nearly circular, unless the equatorial moments of inertia of the earth differ much more than we can suppose probable. The annual motion may differ somewhat from a circle, and be somewhat less regular. There can be no strictly periodic changes in the latitude but these two, but it is quite possible that, owing to secular changes, or changes continued through several years, in the currents of the ocean and atmosphere, corresponding changes of irregular long period may be found in the latitude.

It will be seen that these conclusions are accordant with Chandler's results as regards the double period, but do not fully agree with them in other details. Simon Newcomb.

\section{THE PAST, PRESENT, AND FUTURE WATER SUPPLY OF LONDON.}

I $\mathrm{N}$ a discourse to the members of the Royal Institution on the subject of the metropolitan water supply nearly thirty years ago, I stated that out of every thousand people existing upon this planet three lived in London; and, as the population of London has, in the meantime, doubtless grown at a more rapid rate than that of the rest of the world, it will probably be no exaggeration to say that now, out of every thousand people alive on this earth, four live in London; and therefore, any matter which immediately concerns the health and comfort of this vast mass of humanity may well merit our most earnest attention. Amongst such matters, that of the supply, in sufficient quantity, of palatable and wholesome water, is certainly not the least in importance.

It is not therefore surprising that this subject has received much attention from several Royal Commissions-notably from the Royal Commission on Water Supply of 1867 , presided over by the Duke of Richmond ; the Royal Commission on River Pollution and Domestic Water Supply of Great Britain, presided over by the late Sir William Denison, of which I had the honour to be a member; and, lastly, that of 1892 , of which Lord Balfour of Burleigh was the chairman.

The Royal Institution has, for nearly three-quarters of a century, been prominently connected with the investigation and improvement of the metropolitan water supply; no less than four of our Professors of Chemistry have been successively engaged in this work, namely Profs. Brand, Odling, Dewar, and myself, whilst three of them have been members of the Royal Commissions just mentioned. I may therefore perhaps be excused for bringing the subject under your notice again for the third time.

On the present occasion, I propose to consider the subject from three points of view, viz. the past, the present, and the future; and, for reasons which will appear hereafter, I shall divide the past from the present at, or about, the year I883, and will not go back farther than the year 1828 , when Dr. Brand, Professor of Chemistry in the Royal Institution, Mr. Telford, the celebrated engineer, and Dr. Roget, Secretary of the Royal Society, were appointed a Royal Commission to inquire into the quality and salubrity of the water supplied to the metropolis.

The Commissioners made careful examinations and analyses, and reported as follows. "We are of opinion that the present state of the supply of water to the metropolis is susceptible of, and requires, improvement ; that many of the complaints respecting the quality of the water are well founded; and that it ought to be derived from other sources than those now resorted to, and guarded by such restrictions as shall at all times ensure its cleanliness and purity. (At this time the water was pumped from the Thames between London Bridge and Battersea.) To obtain an effective supply of clear water free from insects and als suspended matter, we have taken into consideration various plans of filtering the river water through beds of sand and other materials, and considering this, on many accounts, as a very important object, we are glad to find that it is perfectly possible to filter the whole supply, and this within such limits in point of expense as that no serious objection can be urged against the plan on that score, and with such rapidity as not to interfere with the regularity of the service."

Before the year I829, therefore, the river water supplied to London was not filtered at all ; but after the issue of this report the companies set themselves earnestly to work to improve the quality of the water by filtration.

$1 \mathrm{~A}$ discourse delivered by Dr. E. Frankland, D.C.L., LL.D., F.R.S., at the Royal Institution on February $2 x$.

NO. I 383 , VOL. 53] 
In the year 1832, and again in 1849 , London was severely visited by epidemic cholera, and the agency of drinking-water in spreading the disease forced itself upon the attention of the observant portion of the medical profession. It was Dr. Snowe, however, who, in August 1849, first formally enunciated the doctrine that drinking-water polluted by choleraic matters is the chief mode by which cholera is propagated.

In every visitation of Asiatic cholera to London, the water supply was either altogether unfiltered or imperfectly filtered, besides being derived from highly polluted parts of the Thames and Lea; and the enormous loss of life, amounting in the aggregate to nearly thirty-six thousand people, can only be attributed to this cause ; for it has now been satisfactorily proved that cholera is, practically, propagated by drinking-water alone; and that efficient filtration is a perfect safeguard against its propagation. Moreover, it is most satisfactory to know that, since the year 1854, no case of Asiatic cholera in London has been traced to the use of filtered river water. The first effect of Dr. Snowe's cardinal discovery was the removal of the intakes of the river water companies to positions beyond the reach of the tide and of the drainage of London. The second was the greater attention paid to the efficiency of filtration.

Such is the verdict in regard to cholera, and the same is true of that other water-borne disease typhoid fever. But unlike cholera, this disease is disseminated in several other ways, and its presence or absence in any locality may not, of necessity, have any connection with drinking-water ; as is strikingly shown by the health statistics of Manchester, since the water supply of this city, derived as it is from mountain sources, is above all suspicion of this kind. These other causes have, during the last ten years, been much mitigated in London by various sanitary improvements; whilst, as shown in the diagram on the screen, there has been no corresponding mitigation in Manchester. There is no evidence whatever that, since the year 1869 , when typhoid fever appeared for the first time as a separate disease in the Registrar General's report, it has been conveyed by the water supply of the metropolis.

Although very soon after the year I 856 , all the water supplied to London was obtained from sources much less exposed to drainage pollution, it was still very carelessly filtered. Previous to the year 1868 there are no records of the efficiency, or otherwise, of the filtration of the metropolitan water supply derived from rivers; but at that time, I began to examine these waters for turbidity. In that year, out of 84 samples, 7 were very turbid, 8 turbid, and ro slightly turbid ; so that, altogether, no less than nearly 30 per cent. of the samples were those of inefficiently-filtered water. The metropolitan water supply then, up to the year I 868 , may be shortly described as derived for many years from very impure sources with either no filtration at all, or with very imperfect filtration ; and afterwards, when the impure sources were abandoned, the supply was still often delivered in a very inefficiently.filtered condition. But after the establishment of monthly reports, the quality of these waters gradually improved in this most important respect down to the year. I 883 , since which time the efficiency of filtration of all the river waters supplied to the metropolis has left little to be desired.

What is it, then, that separates the past from the present water supply of London? In the first place, there is the change of source-I mean the change of the position of the intakes of the several companies drawing from the Thames and Lea, and the total abandonment of the much-polluted Ravensbourne by the Kent Water Company. So long as the water was derived from the tidal reaches of the Thames and Lea, receiving the drainage of an immense population, the risk of infection from water-borne pathogenic organisms could scarcely be otherwise than imminent ; for, although we now know efficient filtration to be a perfect safeguard, anything short of efficiency must be attended with risk in the presence of such extreme pollution.

Nevertheless, the line of demarcation between the past and the present water supply of the metropolis is, in my opinion, to be drawn, not when the intakes of the river companies were removed to positions beyond the possibility of pollution by the drainage of London; but, it must be drawn at the time when efficient filtration was finally secured and ever since maintainedthat is to say, in the year 1884

The removal of turbidity by sand filtration, however, refers only to suspended matter; but there are sometimes objectionable substances in solution, of which organic matter is the most im portant. River water and mountain water, even when efficiently filtered, contains more organic matter than spring or deep-well water; but this is reduced in quantity by storage and especially by filtration, although it can perhaps never be brought up to the standard of organic purity of spring and deep-well water.

\section{The Present Water Supply.}

At present London is supplied with water from four sources : the Thames, the Lea, the New River, and deep wells. Of these, the deep wells yield, as a rule, the purest water, requiring no filtration or treatment of any kind before delivery for domestic use. The river waters, on the other hand, require some kind of treatment before delivery-storage and subsidence in reservoirs, and filtration. The water from the Thames is abstracted at and beyond Hampton, that from the Lea is taken out at two points, viz. at Angel Road near Chingford, by the East London Water Company, and above Hertford by the New River Company, who convey it to Green Lanes by an open conduit twenty-five miles long, called the New River Cut, in which it is mixed with a considerable volume of spring and deepwell water.

Hitherto I have spoken of chemical purity, or comparative freedom from organic matter, only; but the spread of diseases, such as cholera and typhoid fever, through the agency of drinking-water, has no connection whatever with the chemical or organic purity of the water. These diseases are propagated by living organisms of extreme minuteness, to which the names bacilli, bacteria, microbes, and others have been given; and here comes the important question, how does filtration secure immunity from these water-borne diseases.

To Dr. Koch, of Berlin, we are indebted for the answer to this question. By his discovery of a means of isolating and counting the number of microbes and their spores in a given volume of water, we were, for the first time, put into possession of a method by which the condition of water as regards these living organisms, before and after filtration, could be determined with quantitative exactness. The enormous importance of this invention, which was first made known and practised in England in I 882 by the late Dr. Angus Smith, is evident when it is borne in mind that the living organisms, harmful or harmless, contained in water are of such extreme minuteness as, practically, to defy detection by ordinary microscopical examination. But, although the microscope cannot detect with certainty single bacteria or their spores, even the naked eye can easily discern towns or colonies consisting of thousands, or even millions, of such inhabitants.

Ur. Koch's method accomplishes at once two things: it isolates, in the first place, each individual microbe or germ ; and, secondly, places it in conditions favourable for its multiplication, which takes place with such amazing rapidity that even in a few hours, or at most in two or three days, each organism will have created around itself a visible colony of innumerable membersa town, in fact, comparable to London itself for population. By operating upon a known volume of water, such as a cubic centimetre, for instance, the number of separate organisms or their spores in a given volume of the water under investigation can thus be determined.

In order to ascertain the effect of filtration upon the bacterial quality of the water, it is absolutely necessary that the sample should be taken immediately after it has passed through the sand filters ; for, if it be obtained from the delivery mains in townthat is to say, after the water has passed through many miles of pipes - the rapid multiplication of these organisms, except in very cold weather, is such that a water which contains only a single living organism per c.c. as it issues from the filter, may contain 100 or 1000 in the same volume when, after several hours, it arrives at the consumer's premises.

Now, what is the effect of sand filtration, as carried out by the various water companies supplying London, upon the living matter contained in the raw river water? It is simply astounding - for water containing thousands of bacteria per c.c. (a single drop of Thames water sometimes contains three thousand separate living organisms) comes out from those filters with $50,3 \circ$, IO, or even less of these organisms per c.c., or the number of microbes in a single drop is reduced to 2 , or even none.

Rather less than one-tenth of the total volume of water supplied to London is derived by the Kent Water Company from deep wells in the chalk. As it issues from the porous rock into the fisstres and headings of these wells, this water is, in all probability, absolutely sterile ; but by the time it has been

NO. I 383 , VOL. 53$]$ 
pumped up to the surface, it usually contains a small number of microbes. Thus during the year 1892 it contained, on the average, 6 per c.c. ; in $1893, \mathrm{r} 3$; in 1894,15 ; and in 1895,8 .

Thus, although the deep-well water has, from a bacterial point of view, a decided advantage, the filtered river waters are not very far behind; and there is every reason to believe that, with the improvements which are now being carried out by the various river water companies, the Kent Company's water will, before long, be run very hard by the other supplies.

By the examination of the water as it issues from the filters, the utmost freedom from microbes, or maximum degree of sterility of each sample, is determined. This utmost freedom from bacterial life, after all sources of contamination have been passed, is obviously the most important moment in the history of the water; for, the smaller the number of microbes found in a given volume at that moment, the less is the probability of pathogenic organisms being present; and, although the nonpathogenic may afterwards multiply indefinitely, this is of no consequence in the primary absence of the pathogenic ; but, it is only fair in describing the character of the present water supply of London to say that not a single pathogenic organism has ever been discovered even in the unfiltered water as it enters the intakes of the various companies, although these organisms have been diligently sought for. It is sometimes said that the nonpathogenic organisms found in water may be beneficial to man; but this idea is not borne out by their entire absence from the food which nature provides for young animals. Milk, if healthy, is absolutely sterile.

As it is at present impracticable to obtain water, uniformily at least, free from microbes, it is desirable to adopt some standard of bacterial purity, and 100 microbes per c.c. has been fixed upon, by Dr. Koch and myself, as the maximum number allowable in potable water. This standard is very rarely infringed by the London water companies, whilst I have every reason to hope that, in the near future, now that special attention is directed to bacterial filtration, it will not be approached within 50 per cent. This hope is based not only upon my own observations, but also upon the exhaustive and important investigations carried out at the Lawrence Experiment Station by the State Board of Health of Massachusetts, under the direction of Mr. George W. Fuller, the official biologist to the Board. More than six years have already been spent in the prosecution of these American experiments, and many thousands of samples of water have been submitted to bacterial cultivation.

These important experiments, and my own observations on the London waters continued for four years, lead to the following conclusions :-

(r) The rate of filtration between half a million and three million gallons per acre per day exercises, practically, no effect on the bacterial purity of the filtered water. It is worthy of note that the rates of filtration practised by the several water companies drawing their supplies from the Thames and Lea are as follows :-Chelsea Company, 1,830,000; West Middlesex, I,359,072 ; Southwark Company, I,568, I60 ; Grand Junction Company, 1,986,336 ; Lambeth Company, I, 477,688; New River, I,881,792 ; and East London, I, 393,920. Hence, not one of the London companies filters at the rate of two million gallons per acre per day; at which rate in the Massachusetts filters $99^{\circ} 9$ per cent. of the microbes present in the raw water were removed.

(2) The effect of the size of the sand-grains used in the filters is very considerable. Thus, by the use of a finer sand than that employed by the Chelsea Company, the West Middlesex Company is able, with much less storage, to attain an equal degree of bacterial efficiency.

(3) The depth of sand, between the limits of I and 5 feet, exercises no practical effect upon bacterial purity, when the rate of filtration is kept within the limits just specified. Thus the New River Company, with $\mathrm{r} \cdot 8$ feet of sand on their filters, compares favourably with the Chelsea Company, the sand on whose filters is more than twice that depth. Placed in the order of thickness of sand on their filters, the Metropolitan companies range as follows :-Chelsea, Lambeth, West Middlesex, South wark, East London, Grand Junction, and the New River. Placed in the order of efficient bacterial filtration, they range as follows:-Chelsea and West Middlesex (equal), New River, Lambeth, East London, Southwark, and Grand Junction.

(4) When there is such an accumulation of deposit on the surface of a sand-filter that, for practical purposes, sufficient water cannot be made to pass through it, the surface of the filter has to be scraped; that is to say, mud and about half an inch of the sand are removed from the surface. After this operation, there is often an increase in the number of bacteria in the filtered water, and it has been noticed that the increase is greater in shallow than in deep filters, and with high than with low rates of filtration; and there is no doubt that the effect of scraping is considerably magnified when the coarser descriptions of sand are employed, as is the case in the filters of the London water companies. I should therefore like to impress upon the engineers of these companies the desirability of using finer sands than are at present employed.

The lecturer here described a long series of experiments proving that the temperature of the water and the presence or absence of sunshine has little or no effect upon the number of microbes in river water, whilst the presence of flood water is almost invariably accompanied by an enormous increase in the number of microbes, showing that the microbial population of a river is directly dependent upon the volume of water flowing in its bed.

\section{The Water Supply of the Future.}

In view of the rapid increase of the population of London, fears have from time to time been entertained that the water supply from the Thames basin - that is to say, from the rivers Thames and Lea, supplemented by water from springs and deep wells within the basin itself-would soon be insufficient in quantity, whilst the quality of the water taken from the river has, up to comparatively recent date, been considered unsatisfactory. On these grounds various schemes have from time to time been brought forward for the supply of the metropolis from other river basins - from the Wye, the Severn, the river basins of North Wales, and of the lake districts of Cumberland and Westmoreland. It is worthy of note, however, that all the Royal Commissions have arrived unanimously at the conclusion that the quantity of water obtainable from the Thames basin is so ample as to render the necessity of going elsewhere a very remote contingency.

I shall now endeavour to put, very shortly, before you the facts which, in my opinion, prove that both as regards quantity and quality the Thames basin will, for a very long time to.come, afford an abundant supply for the metropolis. There is, indeed, no river basin in Great Britain which affords such an abundant supply of excellent water as that available in the Thames basin. Besides that which flows directly into the rivers, this water is contained in the Chalk, Oolite, and Lower Greensand, which are the best water-bearing strata in the kingdom. From these strata it issues in copious springs of unsurpassed organic purity. For dietetic purposes there is no better water in the kingdom than the underground water of the Thames basin. For sentimental reasons, I should like to see it conveyed to the works of the various companies in special conduits; but we have seen that, on hygienic grounds, it may safely be allowed to flow down the bed of the Thames, if it be afterwards efficiently filtered.

So much for quality, now as to quantity. The basins of the Thames and Lea include an area of upwards of five thousand square miles. Of this, more than one-half, including the Oolitic, Cretaceous, and portions of the Tertiary formations, is covered by a porous soil upon a permeable water-bearing stratum. The remainder is occupied by the Oxford, Kimmeridge, Gault, and London clay; being thus covered by a clay soil upon a stiff and impervious subsoil. The annual rainfall of the district averages twenty-eight inches. The rivulets and streams of the Thames basin are formed and pursue their course on the clay land. There are no streams on the chalk. That which falls upon the porous stratum and does not evaporate sinks, mostly where it alights, and heaps itself up in the water-bearing stratum below, until the latter can hold no more. The water then escapes as springs at the lowest available points. Innumerable examples of these springs occur all round the edge of the Thames basin, and at various points within it. Thus from the Chalk they are ejected at the lip of the Gault, and in the Oolitic area by the Fuller's earth below it, or by the Oxford clay, geologically, above it.

According to the gaugings of the engineer of the Thames Conservancy Board, there passed over Teddington Weir, in $1892,387,000$ millions of gallons, equal to an average flow of ro6o millions daily. In the following year, 1893, there passed over this weir an aggregate of 324,227 millions of gallons, or a

NO. I 383 , VOL. 53$]$ 
daily average of 888 millions of gallons, the average for the two years being 974 millions of gallons; and this number does not include 120 millions of gallons daily abstracted by the five London water companies who draw their supplies from the Thames. Thus, in round numbers, we may say that, after the present wants of London have been supplied from this river, there is a daily average of nearly a thousand millions of gallons to spare. Surely it is not too violent an assumption to make that the enterprising engineers of this country can find the means of abstracting and storing, for the necessary time, onefourth of this volume.

As regards the quality of this stored water, all my examinations of the effect of storage upon the chemical, and especially upon the bacterial quality, point to the conclusion that it would be excellent; indeed, the bacterial improvement of river water by storage, for even a few days, is beyond all expectation. Thus the storage of the Thames water by the Chelsea Company for only thirteen days reduces the number of microbes to one-fifth the original amount, and the storage of the river Lea water for fifteen days by the East London Company reduces the number, on the average, from 13,693 to $275^{2}$ per c.c., or to one-fifth. Indeed, quietness in a subsidence reservoir is, very curiously, far more fatal to bacterial life than the most violent agitation in contact with atmospheric air ; for the microbes which are sent into the river above the Falls of Niagara by the city of Buffalo seem to take little or no harm from that tremendous leap and turmoil of waters; whilst they subsequently, very soon, almost entirely disappear in Lake Ontario. Thus it is not too much to expect that storage for, say, a couple of months, would reduce the number of microbes in Thames flood water down to nearly the minimum ever found in that river in dry weather; whilst, by avoiding the first rush of each flood, a good chemical quality would also be secured. There is therefore, I think, a fair prospect that the quantity of water derivable from the Thames at Hampton could be increased from its present amount (120 millions of gallons per diem) to 370 millions.

Again, in the river Lea, although here the necessary data for exact calculation are wanting, it may be assumed that the present supply of fifty-four millions of gallons could be increased by the storage of flood water to 100 millions of gallons per day. To these volumes must be added the amount of deep-well water which is obtainable from those parts of the Thames basin which lie below Teddington Lock; and in the Lea basin below Lea Bridge, and which was estimated by the last Royal Commission at rather more than $67 \frac{1}{2}$ millions of gallons. Thus we get the grand total of $537 \frac{1}{2}$ millions of gallons of excellent water obtainable within the Thames basin, the quality of which can be gradually improved, if it be considered necessary, by pumping from the water-bearing strata above Teddington and Lea Bridge respectively; instead of taking the total supply from the open rivers above these points. Such a volume of water would scarcely be required for the whole supply of the water area of London at the end of fifty years from the present time, even supposing the population to go on increasing at the same rate as it did in the decade $188 \mathrm{I}-9 \mathrm{I}$, which is an assumption scarcely likely to be verified.

In conclusion, I have shown that the Thames basin can furnish an ample supply for fifty or more years to come, whilst the quality of the spring and deep-well water and the efficientlyfiltered river water would be unimpeachable. To secure these benefits for the future, storage must be gradually provided for II, 500 millions of gallons of flood water, judiciously selected, in the Thames Valley, and a proportionate volume in the basin of the Lea ; whilst filtration must be carried to its utmost perfection by the use of finer sand than is at present employed, and by the maintenance of a uniform rate during the twenty-four hours.

The lecturer concluded as follows. There nothing heroic in laying pipes along the banks of the Thames, or even in making reservoirs in the Thames basin. They do not appeal to the imagination like that colossal work-the bringing of water to Birmingham from the mountains of Wales ; and there is little in such a scheme to recommend it to the mind of the enterprising engineers of to-day. Nevertheless, by means of storage, by utilising springs, by sinking deep wells, and by such comparatively simple means, we have, in my opinion, every reason to congratulate ourselves that for half a century, at least, we have at our doors, so to speak, an ample supply of water which, for palatability, wholesomeness, and general excellence will not be surpassed by any supply in the world.

No. I 383 , VOL. 5.3$]$

\section{UNIVERSITY AND EDUCATIONAL INTELLIGENCE.}

CAMbringe. - The Conference on Secondary Education, held in the Senate House on April 2I and 22, was largely attended by representatives of all the various educational authorities. The discussions were in some cases animated, and turned largely on the provisions of the new Education Bill; but the resolutions prepared, in support of the Report of the Royal Commission on Secondary Education, were in every instance passed by large majorities.

Dr. A. A. Kanthack, of St. John's College, has been appointed Deputy-Professor of Pathology for the present Term, in place of Prof. Roy, who is unable to lecture.

Dr. H. Frank Heath, Fellow of University College, London, has been elected Assistant Registrar in the University of London, in the place of Mr. Dickens, who has succeeded Mr. Milman as Registrar.

A SPECIAL meeting of the Board of Governors of the Yorkshire College was held on Wednesday, April 23, in the Philosophical Hall, Leeds. The business before the meeting was to obtain the assent of the Governors to the borrowing by the Council of the College of $£ 30,000$ at 3 per cent. per annum on a mortgage of the real estate of the college situate in College Road (except such portion as is held in trust for the Cloth workers' Company), and of the new Medical School in Leeds. The motion was ultimately agreed to.

THE annual report of the Whitworth Trustees has just been published, in which it is stated that a sum of $£ \mathrm{I} 0,000$, a portion of the surplus from the I 887 Exhibition, has been handed over to the Technical Instruction Committee of the Manchester Corporation for the purpose of erecting an additional wing to the School of Art in Cavendish Square of that city. We thought that satisfactory arrangements had been made for the accommodation of this art school in the new technical school which is being built at an estimated cost of $£ 200,000$.

THE following are among recent appointments:--Dr. A. Fleischmann to be extraordinary professor of anatomy and zoology in Erlangen University, and director of the Zoologischen Universitäts, Anstalt ; Dr. Pockels, privat docent in physics at Dresden Technical High School, to be professor ; Dr. Oertel to be observer at the Königlichen Sternwarte in Munich, and Dr. Julius Bauschinger, of the same observatory, to be full professor of astronomy in the University of Berlin; Dr. H. W. Bakhuis Rosebom to be professor of chemistry at the University of Amsterdam, and Dr. A. Bistrzycki to be professor of analytical and technical chemistry in the University of Freiburg.

THE Paris correspondent of the Times states that the General Council of the Paris Faculties has decided to send several delegates to the meeting of the Franco-Scottish Society to be held in Edinburgh in 1897. It has also decided to be represented at the jubilee of Lord Kelvin's connection with the University of Glasgow in June next. A similar decision was taken in reference to the Princeton College celebration fêtes. In this connection the Council passed a resolution in favour of closer relationship between French and foreign universities. It was declared that France held too much aloof from these international festivals, and did not sufficiently try to extend a knowledge of her scientific activity. But however this may be, it is certain that we have yet to cultivate the hospitality always. freely and lavishly given when British men of science visit their French confrères.

THE Report of the Council of the City and Guilds of London Institute upon the work of the Institute for the year I895 has come to hand. Reference is made in it to the assistance which Prof. Huxley gave to the Committee appointed in 1877 to prepare an educational scheme. It was fitting that some permanen record of his connection with the Institute should be established, and the Council have been gratified to receive from the Fishmongers' Company an intimation that, in consideration of the eminent and important services rendered by Prof. Huxley to the cause of technical education, the Court of that Company have determined to found a Scholarship of $£ 60$ a year to be called the " Fishmongers' Company's Huxley Scholarship," to be awarded to a scholar of the Technical College, Finsbury, to enable him to proceed to the Central Technical College. In recalling the work of their late Chairman and of Prof. Huxley in the early years of the Institute, the Council are reminded of the great extension which this movement has undergone during 